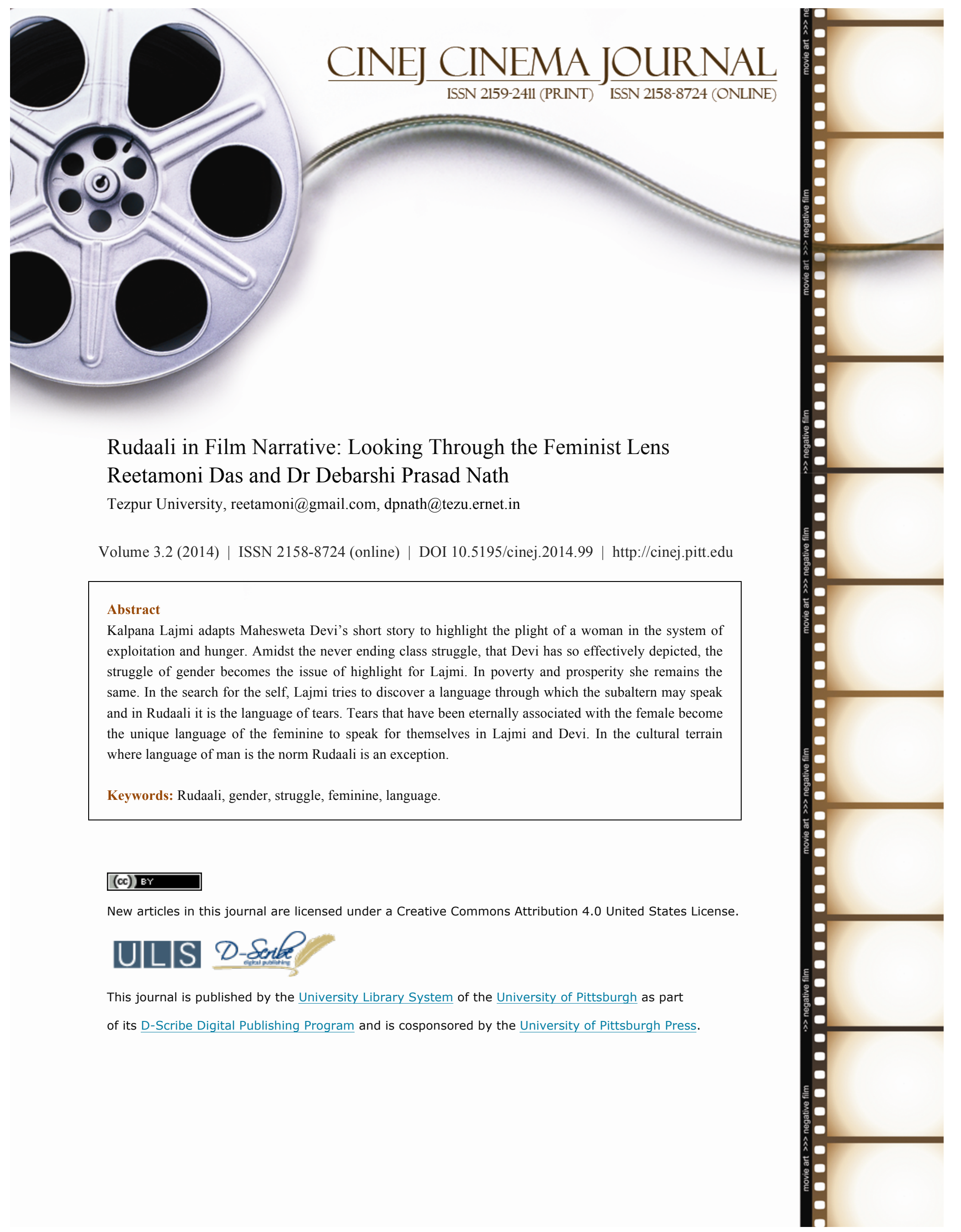




\section{Rudaali in Film Narrative: Looking Through the Feminist Lens}

\section{Reetamoni Das and Dr Debarshi Prasad Nath}

\section{Introduction}

Throughout the history of civilization the role and place of the female gender has been distinct. In the Indian context the idealized woman is the obliging Sita. Manusmriti has detailed guidelines on how the life of a woman should be. In childhood she should be a subject to her father, in youth to her husband and when her husband dies, to her children. A woman must not strive to separate herself from her father, husband and sons (Gokulsing and Dissanayake 1998, 75-76).

In coherence and continuance with history and myth, women continue to be represented in exemplified and typified roles in various forms of art to which cinema is not an exception. The image of a mother, wife, lover, daughter, sister and many such preset roles make up the daily menu of film scripting. The feminists look at cinema as a cultural practice representing myths about women and femininity, as well as about men and masculinity. Claire Johnston said the sign 'woman' can be analyzed as a structure, a code or convention. It represents the ideological meaning that 'woman' has for men. Women are often represented as 'not-man'. The 'woman-as woman' is absent from the text of the film (Johnston 1991, 26).

Women in cinema are often fragile, gullible and yielding. They are in constant need of a male super-hand to guard against the odds. In horror films the women are often portrayed as jumpy, nervous, fearful women who called out and screamed in terror. The women can be strong and commanding only when circumstances force them to do so (Brewer 2005, 30-49). 
Various feminist criticisms have tried to give counter arguments and views regarding the projection of the feminine. In her analysis of the historical development of women's writing, Elaine Showalter presents three important stages. The first stage was more or less about the imitation of the 'mainstream' patriarchal literary tradition; the second stage was the one of protest against the standards of this dominant tradition concerning social values and rights; the third stage in the historical tradition of women's writing is one of self-discovery and self-assertion. Showalter identifies these stages as Feminine, Feminist and Female (Goel 2010, 405).

Psychoanalysis has tried to depict woman as suffering from the fear and complex of castration. It is this realization and fear of the female that she idolizes the father and in an attempt to make good the lack that she desires to possess a symbol for it. Mulvey says that psychoanalytic theory should be used as a political weapon, demonstrating the way the unconscious patriarchal society has structured film. She says that that 'we can begin to make a break by examining patriarchy with the tools it provides' (Mulvey 1999, 833-834). By breaking away from classical cinema can the gaze be turned away from the female form and thus do away with the voyeuristic scophohilic pleasures. Mulvey cites the example of Jean-Luc Godard's New Wave cinema where the formation of the fixation on the female body is averted by rapid cuts and jump cuts. Newer ways and techniques of film making thus can be a tool for the women directors to experiment with the content and form of cinema that will break the stereotypical and hierarchal images. Technological advances have made possible the development of an alternative cinema, a cinema for women. The alternative cinema provides a space for the cinema to be born which is radical in both political and aesthetic sense and challenges the basic assumptions of the mainstream film (Mulvey 1999, 834). 


\section{Rudaali: The Background}

Directed by Kalpana Lajmi, Rudaali is based on a short story by the same name written by Mahashweta Devi. The film is set against the physical and cultural backdrop of Rajasthan. The film revolves around the life of Sanichari, a woman in rural Rajasthan. She belongs to the most impoverished lot of the village population. Her husband is a bonded labourer at the landlord's place. Her father died soon after her birth and she was abandoned by her mother. Her husband is a drunkard with little to spare for the family requirements. She looks after her ailing mother-in-law and her little son. As the story progresses she loses her mother-in-law and her husband. Her son runs away after growing up.

Sanichari starts leading a solitary life when a rudaali, professional mourner, enters her life. Rudaali are women of a low caste in Northern India (particularly in the state of Rajasthan) who perform mourning dances and songs at the funerals of higher caste men (Hurlstone 2011, 10). The rudaali, Bhikni and Sanichari develop a warm bond between them. Sanichari in all these years opens her heart to Bhikni. As the story comes to an end Sanicahri as well as the audience learns that Bhikni was indeed the mother who had abandoned her as a child. This piece of news works as the trigger to burst Sanichari's pent up emotions. She cries for the first time in her life and becomes a rudaali.

\section{Rereading Rudaali}

Mahaesweta Devi's Rudaali is a tale about the struggle of the impoverished and the environment of denial in which they live in. Human life has no dignity for the poor and they are the exploited lot. It is the landlords who enjoy all the luxuries of life when the ones who work in their field are left to starve. Mahasweta Devi takes death as a metaphor to reflect this

CINEJ Cinema Journal: Rudaali in film narrative: Looking Through the Feminist Lens

Volume 3.2 (2014) | ISSN 2158-8724 (online) ｜ DOI 10.5195/cinej.2014.99 | http://cinej.pitt.edu 
eerie irony of life. Living for the poor is hard but dying is even tougher. Lajmi's rendering of the story is very much different from the original written by Devi and the play version adapted by Usha Ganguly. Devi denies a feminist twist in her story and makes it more of a class play. For her gender gets incorporated in the discourse of class and cannot be emphasized at the expense of the other. To her it is a tale written by a writer irrespective of gender, about people's struggle and their confrontation with the system (Katyal 2010, 20-21). Usha Ganguly on the other hand, though likes to restrain a fashionable use of the term feminism puts her belief in the 'liberation of women and their freedom and towards which she would like to work as a theatre worker and teacher' (Katyal 2010, 2). In Ganguly the feminist sentiment are aroused and in her own words, she finds scope in the story more to paint in feminist colours apart from the social and class dynamics in play.

\footnotetext{
.......I strongly believe that Rudaali is a women's text. I believe that the Indian woman, whether it's Sanichari or some one from the middle or upper class, is highly exploited in our society. Somehow, in Rudaali, I see Sanichari protesting against society on the whole ((Ganguly 1993) Katyal 2010, 36).
}

Lajmi has differed in many ways in her film from the original not only to give a feminist twist to the original but also to match the screen timing. In the film we do not see Sanichari's brother-in-law and his wife nor does the story extent to her grandson Haroa. In the film, the role and characteristics of Haroa is merged into Budhwa. In the film Budhwa does not die but runs away after his wife Parbatia leaves home after quarrelling with Sanichari. He never returns to his mother. Lakshman Singh's character is not elaborated in Devi's play but in the film the character has many hues. He is sober version of his father, Ramavatar Singh and lectures on the futility of the class and caste system. Set in the pre-independence era Lakshman 
Singh is politicized by Lajmi. He is an example of the class of landlords who are aware of the new social dynamics and a threat to their rule brought by the freedom movement. The twist in the characterization of Lakshman Singh's character also paved a way to create an association between him and Sanichari. Lakshman Singh is a representation of the social cross roads where newer ideas lingered in the society but the older were also difficult to give up. Lakshman Singh may lecture about class equality but inherits his father's wealth. His desire to own Sanichari is a depiction of the feudal tradition that he is ingrained into. Again the film does not have Dhatua as an intelligent peer of the community who guides her in many ways. The role of Dhatua as Sanichari's moral guardian and confidante is replaced by the character of Bhikni in the film. By doing this the director has not only saved some screen time but also created a strong female that is capable to see through the shams and deceptions of the society they live in and exploit them for their own interest. Discarding the role of Dhatua paves way for the feminist agenda of the film. In Lajmi the enlightenment come from the within (the female), not from inspiration from an external source resulting in self discovery.

In Mahasweta Devi and Usha Ganguly, women of the higher caste and class are not very different from their male counterparts in their vanity, sham and upholding their class status. Their obsession with the elaborate funeral ritual as a show of wealth and power is comparable to such pompous traits displayed by patriarchs. In Devi they do not seem to suffer the gender issues. But in Ganguly she is taunted for being the mother of a daughter and in Lajmi she is the same stoic and indecisive doll as are the other women outside the walls of the haveli. Her privileged existence does not benefit her existence as a woman. In Lajmi the women in the haveli do have a life if luxury and vanity but in regards to their importance and presence as an individual they are no less than the Sanicharis. Lakshman Singh's wife spends

CINEJ Cinema Journal: Rudaali in film narrative: Looking Through the Feminist Lens

Volume 3.2 (2014) | ISSN 2158-8724 (online) ｜ DOI 10.5195/cinej.2014.99 | http://cinej.pitt.edu 
buckets of water while bathing which is a luxury for Sanichari but she seldom steps out of the haveli and have no say in the decision making process of her husband. It is her husband who decides the singer at the birthday celebrations of their son and overrides her will to choice Sanichari to perform in it.

Mahasweta Devi uses death as a metaphor to show the class struggle and predicament of the poor. Death for the rich becomes another occasion to display their wealth and power. It is a lavish affair intended at increasing their standing among the peers by organizing a glittering kriya. On the other hand, for the poor, death is harder than life. The social system that oppresses them throughout life preys on the dead. There are rituals to be performed and offerings to be done that they cannot afford. Unable to afford a proper living and no access to medication, there are many deaths in Sanichari's family and her poverty does not let her time to mourn for them. It is death that in the end becomes a tool for subversion for the poor. They mock back at the rich and earn their livelihood from it, as they are the ones facilitating their suppression, poverty and untimely deaths. Tears are a luxury for the poor and they cannot spend them in vain without getting anything in return-money, rice, clothes (Katyal 2010, 114).

Kalpana Lajmi keeps the primary theme of death and poverty intact in the film but wraps it in the cloak of feminism. Amidst all struggle and poverty it is the women trying to hold her ground. She uses the language of tears not only to mock back at her oppressors but also at the same time use it to tell her individual tale. Lajmi narrates the particular experiences of women amidst the harsh conditions. Though Sanichari's experiences have the colours of her class and community it is not same as the men folk. By virtue of being a woman, she is won by her husband in a gambling game. She is also not free from the many roles of a woman that 
society puts on her. While her husband has the luxury to drown the day's exhaustion in liquor she is entrusted with the responsibility to feed and look after her family. Prostitution is one option that the women are forced to fall back in all the three versions as an outcome of their poverty and corrupt social dynamics. Lajmi in her film gives Bhikni the role of the guide that Dhatua as a peer has played in the original short story. The introduction of Bhikni as the guide and philosopher may be perceived as the film maker's insistence to bring on self realization to the Sanicharis about their situation and how to exploit it for their benefit and survival. The wisdom from a male counterpart may dilute the feminist agenda ingrained in the film.

But the three writers highlight the dynamics of the social and class hierarchy and the position of the subaltern in it. The ultimate victory comes for the subaltern-feminist or not, by learning to use the same oppressive rules for their own benefit and tell their tales. As Anjum Katyal has written:

In both incarnation of 'Rudali', it has been the women auteur who has wrought and then rewrought this text which revolves around the life of a woman-the poor, low-caste Sanichari. Each version is mediated by the differing purpose and agenda of its respective author, resulting in strikingly different texts which have one feature in common-they are perceived as women-intensive projects and perceived as feminist texts (Katyal 2010, 1).

The three authors use the same base to narrate their experiences and world in style very distinct from each other. Though Mahasweta Devi is reluctant to label her text as feminist, the intensity of the portrayal of the protagonist and other women characters in the story do indicate a female mind at play exhibiting ethnography of women (Hurlstone 2011, 10). It is the women who take position against the tide and mocks back at them (their oppressors) using tears as the weapon using a tradition and occupation that has been associated with them.

CINEJ Cinema Journal: Rudaali in film narrative: Looking Through the Feminist Lens

Volume 3.2 (2014) | ISSN 2158-8724 (online) | DOI 10.5195/cinej.2014.99 | http://cinej.pitt.edu 


\section{The Feminist Reading}

Sanichari belongs to the community that stands at the lowest rung of the economic and caste ladder. Her name is an embodiment of the day she was born, Saturday (considered inauspicious). A little while after her birth, her father passes away to ensure a cursed existence for her. This 'fact' about her birth is repeated many times in the film in dialogue form through Sanichari, Bhikni and others. Sanichari is married to a man named Ganju, who worked as a labourer at the landlord's house. Ganju, a drunkard and has no time for his wife and son as well for his ailing mother. Ganju had won Sanichari in a gambling game, brought her to his village and married her. She feeds the family with the little money that Ganju spares from drinking. She also performs the cremation rituals of her mother-in-law in his absence. Sanichari, a self dependent woman, neither complains nor cries.

Sanichari caught the fancy of the local landlord's son Lakshman Singh. Though the latter talks about equality and disbelief in caste and class, Sanichari is skeptical and scared of the advances. Though some attraction was apparent from the screenplay, it would be hard to guess if there was any physical liaison between the two. This obscurity in the relationship of Lakshman Singh with Sanichari is also prominent in his character depiction. The two song sequences (dil hoom hoom kare and jhuti muti mitwa) depict Sanichari's emotions where Lakshman Singh is present only behind the shadows. This also tells a lot about the latter's character. Lakshman Singh is the landlord and evidently much above Sanichari in the social ladder. He has no promises for her to provide a concrete shape to his attraction for Sanichari. His lectures of equality do not override the class and caste difference between the two. His elevated status becomes evident when he first meets Sanichari. Both are introduced in long shots amidst the arid desert implying the insignificant and susceptible human existence amidst 
the forces of nature. But Lakshman Singh comes ridding a camel and the camera elevates him against Sanichari in a clear indication of their societal standing. Again his changed outlook does not seem to be manifested in his relationship with his wife, who is confined to the boundaries of the haveli.

I. In another turn of events, Sanichari loses her husband to an outbreak of cholera. Manusmiriti says that a woman is expected to be unwaveringly obedient to her husband, and after his death must take every effort to honour his memory (Gokulsing and Dissanayaka 1998, 52). Sanichari was a clear violation to such diktat and does not cry at the demise of her husband. In her conversations with Bhikni we hear Sanichari mentioning that there was no time for her to cry on any of the 'misfortunes' suffered by her. She had to carry on with her daily routine and do what has to be done. When her mother-in-law died the immediate work that had to be done was to arrange for the funeral as waiting for the morning meant more rituals to follow for which she had no money. When her husband died the government authorities quickly buried the bodies fearing that the epidemic might spread further. Her declarations about the impoverished existence that left her with little time to shed tears allude to the class struggle and the fight of the underprivileged for survival. This class struggle also entwines the liaison between her and Lakshman Singh. Capitalism as an institutionalized form of oppression is based on profit for private owners and sets into motion hostile social relations in classes. These classes have their relations mediated through different cultural behaviour and institutions. The domination of men over women is based on a similar institutionalized system of oppression. The class struggle further denies a woman power based on her position (Park, 1972). According to Socialist feminism prostitution is also a manifestation of the corrupted society marked by class distinction. 
Sanichari's daughter-in-law in the film is already from the prostitute colony when her son brings her home. On the other hand, in the original short story, she leaves her dying husband and ends up as a prostitute. In both the versions she is victim of her poverty. Her vulnerable situation is a license for her exploitation. This is also apparent in the relationship of Sanichari with her daughter-in-law.

II. The adverse conditions of Sanichari's life can be equated with the vast Thar and its pale colour. Colours play a distinct role in the cinematography of the film. Sanichari as a young woman is depicted in bright colors. The playfulness in her eyes is reflected in the vibrant colours of her dress. But as the story progresses and we see a more mature woman, sober colours adorn her. Like the people in her life the colours also fade away gradually. After the death of her husband she is also not to wear anything colourful according to the customs.

III. In the midst of the overbearing forces of existence and society she struggles to find her self. She is in a constant search in the vast space of nature and culture. She is a mother who yearns for her child. She is introduced in the film with her son. The same scene also makes her fear of losing him apparent when she mentions that he has got the same penchant for wandering as his grandmother. It is also perhaps this fear of losing her son that does not let a cordial relationship to be established with her daughter-in-law. However, Sanichari accepts her daughter-in-law only after learning that the latter was pregnant with her grandchild. The yearning for the child in the film is prominent not only in Sanichari but also in her mother-in-law. Bhikni also displays the same maternal instincts when she learns of Sanichari's identity. On the other hand, there is Budhwa's wife who after a quarrel with her mother-in-law aborts her child. Her assertion to 
Sanichari that it was indeed her grandchild that she aborted may be read as a negation to the Freudian mother. But others enjoy their motherhood. This emphasis on motherhood is singular to the film. It is the separation pangs from her mother that tears roll down her cheek for the first time. The delight of motherhood enjoyed by the women can be explained with reference to what Julia Kristeva says:

IV. The arrival of the child, on the other hand, leads the mother into the labyrinths of an experience that, without the child, she would only rarely encounter: love for an other. Not for her-self, nor for an identical being, and still less for another person with whom "I" fuse (love or sexual passion). But the slow, difficult, and delightful apprenticeship in attentiveness, gentleness, forgetting oneself. The ability to succeed in this path without masochism and without annihilating one's affective, intellectual, and professional personality-such would seem to be the stakes to be won through guiltless maternity (Kristeva 1981, 31).

V. Sanichari lives a lonely life after her son deserts her when a rudaali comes to her village and stays at her house. The two women develop a warm bond. Bhikni is amazed at her inability to cry and urges Sanichari to become a rudaali. She tells her to cry at the death of her oppressor. She said that it was the only way to release the anger towards the ones who had wronged her. Bhikni demonstrates how she produces phony tears and performs at the mourning of the wealthy men. Towards the end of the film, Bhikni leaves a dying message for Sanichari that she was her mother who had forsaken her as a child. It was as though the virtual umbilical cord between the mother, who had deserted her was snapped for the first time. She is split form the maternal body; she moves from the biological to the social; she moves from nature to culture that shaped the course of her existence, that 
gave her identity of the 'cursed one'. The pain of the split overcomes her. She cries and becomes a rudaali. In her search Sanichari discovers the pre-Oedipal mother and her identity attached with that mother. Her search is not the replacement of the self but becomes one with nature; it ends with her discovery of the self.

VI. Tears in Rudaali are not symbol of the helpless woman. It is an understanding of who one is. Bhikni asks Sanichari to cry at the death of those who have wronged her, those who have despised her and those who have mocked her. It was her chance to mock back at them. Though Sanichari becomes a rudaali and performs at the mourning of the death of the landlord, the tears are not coloured by protest or the mimicry of Bhikni. Her tears are an acknowledgement of her identity as a woman. She has discovered a new language to express herself; she has discovered the pre-Oedipal language. She uses this language to speak her mind. She does not resort to imitation that Bhikni made use of but she is Showalter's 'female' who has discovered her self and who writes her own tales.

Sanichari is a woman and as a norm she must cry her heart out at the death of her mother-in-law, husband, her poverty, loneliness and when her son ran away. But she could not. She is the 'dry' Sanichari. People are surprised by her inability to cry. Lajmi's Rudaali is an antithesis to the popular belief that a woman is a storehouse for tears. Here the women cry to express themselves. That is their only mode of expression. Sanichari's subsequent transformation into a rudaali, is not only the way to vent out her stockpile emotions but can also be read as the subversion of the societal rendering of the gender concept. As Cixous writes:

The future must no longer be determined by the past. I do not deny that the effects of the past are still with us. But I refuse to strengthen them by repeating them, to confer upon them an irremovability the equivalent of destiny, to confuse the biological and the cultural. (Cixous 1976, 875). 
Sanichari produces an image of stoic resistance to being a subject of desire. The lala and pandit lures after Sanichari. She is also the desire of Lakshman Singh. While her relationship with Lakshman Singh is not apparent, her resistance to the other two is perceptible. In the attempt to depict the integral in the screenplay Lajmi abstains from explicit use of the camera to create voyeuristic images. The gaze here produced is through the character of Lakshman Singh. As an object of desire Sanichari is also an object of gaze for Lakshman Singh. The camera can not only produce screen images but also spaces beyond. Camera technology and camera movements combine with invisible editing all tend to blur the limits of screen space (Mulvey 1975, 841). Virginia Woolf said that language use is gendered (Barry 2002, 87). The camera as such is not a gendered object rather the use of the camera is gendered. The gaze that is created trough the camera is gendered. Women film makers can deviate from this gendered use of the camera and develop their own language of the camera as Lajmi does in her Rudaali.

In Rudaali we are exposed to two categories of women. Valiurrahaman in his reading of Usha Ganguli's Rudaali, a play adaptation of the same book writes that in Ganguli's play two women are prominent one challenging and struggling and the other submissive and reluctant. While Sanichari and Bhikni may be the challenging and struggling kind, Budhwa's wife, the old maid at the landlord's house might be the submissive and reluctant kind.

Lajmi's Rudaali is a poignant rendering of the social scenario and the oppressive hierarchy that existed in the country at that time. It is a silent but prominent display of the oppressed and the oppressor. In this tale of the oppressor and the oppressed, Lajmi highlights the tale of the women folk. On the one side are the high class women who have access to all luxuries and ignorant of the hardships of the world. Attended by several maids and dressed in their finest 
they are the decorations of their home. The high class women do not mourn in open at the death of someone. A rudaali is hired to mourn loudly at the death of an aristocratic man. Contrary to these women are the Sanicharis and Bhiknis bearing open to the world, seeing and knowing its ways and in the process also bearing the brunt of it. They do not or rather cannot stay in purdah. Their lives are like the dessert in which they live- harsh, dry and pale. Sanichari represents these women in the film. She is the bold and tough woman. Her will power and strong disposition represents all that who cannot express it. Lajmi in the film takes up the story a woman in the backdrop of a prolonged tradition and creates her own rendering of it. While feminists need to deconstruct the patriarchal images and representations of 'Woman', they historically need to establish their female subjectivity at the same time (Smelik 1991, 494).

In Rudaali Lajmi renders the story of a woman who in all adverse conditions writes her own history. She neither conforms to the societal constructions of the gender nor the hierarchical communal life. Her individuality is upheld and when she becomes a rudaali it is not to pursue the norms of the traditional profession but as an expression of her resentment against the subjugation and sham. The rudaali has the 'impregnable language that will wreck partitions, classes, and rhetorics, regulations and codes, they must submerge, cut through, get beyond the ultimate reserve-discourse, including the one that laughs at the very idea of pronouncing the word silence (Cixous 1976, 886). Rudaali does not stay in the purdah but comes out and cry out loud. Blended with the history of the impoverished Lajmi builds a separate and unique distinction and individuality of the feminine through the character of Sanichari in Rudaali. As Cixous writes in Laugh of Medusa:

Because she arrives, vibrant, over and again, we are at the beginning of a new history, or rather of a process of becoming in which several histories intersect with one another. As subject for history, woman always occurs simultaneously in several places. Woman un-thinks the unifying, regulating history that 
homogenizes and channels forces, herding contradictions into a single battlefield. In woman, personal history blends together with the history of all women, as well as national and world history. As a militant, she is an integral part of all liberations. (Cixous 1976, 882).

\section{An alternative language}

VII. The central character of Rudaali may also be read as a symbolic telling of the story of the director herself. Both Sanichari and Lajmi are in a search of a language that would be expressive of their thoughts and emotions, of their feelings and their bodies. Thus both the story of Sanichari and Lajmi are essentially about quest. Whereas Sanichari is involved in the search of finding out who she really is, Lajmi, in the vast arid landscape of male cinematic traditions searches for a language with which to give voice to her thoughts. Thus, within the cinematic scope Sanichari weaves a language of tears. Lajmi on the other hand uses her camera to give expression to her creative yearning. It is not a mere coincidence that whereas Mahasweta Devi's story ends on a note of protest, the film ends when Sanichari breaks down into tears.

The conceptions of women onscreen are shaped by the conceptions of women working behind the scenes, perpetuating both the representation of women onscreen and the male domination of the industry. However, women's involvement in key film industry positions, particularly screenwriting, can change the portrayal of women in film. It is therefore interesting that Kalpani Lajmi falls back on the story of one of the most powerful women writers of our times and gives it a cinematic rendition. The films that involve women in integral roles in the production often provide conceptions of women that oppose the dominant representations (Toivonen 2002, 2). Through the language of the camera women directors like Lajmi delves to write a different and unique history of women in cinema.

CINEJ Cinema Journal: Rudaali in film narrative: Looking Through the Feminist Lens

Volume 3.2 (2014) | ISSN 2158-8724 (online) ｜ DOI 10.5195/cinej.2014.99 | http://cinej.pitt.edu 
While there have been many film makers who have tried successfully to depict the saga of women on screen, the works of male directors like Ketan Mehta, Mehboob Khan, Rajkumar Santoshi have earned a lot of critical acclaim in terms of their depiction of women. Released in the same year as 'Rudaali', the film 'Damini' by Rajkumar Santoshi went on to gather many awards including a National Film Award. The film tells the story of a woman fighting for the justice of a rape-victim. The sensitive issue caught the attention of the audience and the critics alike and the film went on to be a major success. The protagonist fights with the help of her husband and a lawyer. However, while admiring the strength of Damini one has to admit that she is still projected as someone who is vulnerable enough to need a male hand to guide and protect her. In stark contrast is the character of Sanichari, who has learnt the ways of the world through difficult circumstances and in the end is able to subvert them for her own benefit. Damini opens with the titles of the film flashing the face of the female lead in every frame. However, this importance given to the character gives way to male macho and bravado as the story progresses. The claim of the protagonist is validated in the end when her husband repeats the 'truth' or 'cause' for which she is fighting. For a sensitive issue like rape which is the ultimate violation of the female body, the film fails to invoke a unique female language to address it. In Rudaali, Lajmi comes up with a new language for the women to tell her tale and write her history. Tears, which have been associated with women for centuries, become the tool for the protagonist to fight back against the society that has abused and exploited her from time immemorial.

Lindiwe Dovey writes in her article about women film makers in Africa that in the cinema of women the one-dimensional male views about women makes way for a new look of the feminine (Dovey 2011, 33-35). Lajmi, powered by an eminent writer, builds a character that 
without the presence of a male super hand manages to find a language for herself amidst the harsh conditions. To bring forth a feminist discourse in cinema is not possible without the involvement of the women film makers. Like in the feminist movement and feminist criticism would not have occurred....

\begin{abstract}
........without a generation of women who liked books, graduate students, assistant professors, editors, writers, faculty wives, highly educated products of the academic expansion of the 1960s whose avid, devoted, socially-reinforced identifications with fictional heroines were coming into conflict with the sexist realities they encountered everyday (Showalter 1984, 34).
\end{abstract}

Cinema as an audio-visual medium is capable of putting the condition of the women in their historical and social situation and produce a politicized discourse of it. Women film makers like Lajmi has adopted the tale of the subalterns and paint them in feminist colours. Away from the gaze that is so fixedly placed on the screen, a narration of the feminine is built by directors like Lajmi as she challenges the cinematic codes and their relationship to formative external structures so rigidly followed by mainstream cinema (Mulvey 2009, 26).

The women directors in their films have made an attempt to depict vigorously the feminine as they themselves have exclusively experienced as a women. Female language, according to Kristeva, is derived from a pre-Oedipal period of fusion of the mother and child. It is when the feeling of distance and the same time association from the maternal body dawns on Sanichari that she discovers a new language for herself and in Rudaali it is the language of tears. Associated with this maternal, female language is not only a threat to culture, which is patriarchal, but also a medium through which women may be creative in new ways breaking the hierarchically gendered social relations in general. Lajmi not only creates a strong female (Showalter's female) but uses the medium to pave a way for the women to tell her tale on the 
screen. She is the Écriture féminine placing experience before language, and privileging nonlinear, cyclical writing that evades "the discourse that regulates the phallocentric system. The narration of events breaks away from the popular structural and logical linear narrative to oscillate between Sanichari's past and present.

While Mahasweta Devi's short story ends in a note of protest Lajmi ends her film with the discovery of the self. She is Showalter's female - bringing her own experience into play and telling her story. While for Sanichari it is the language of tears, for Lajmi, it is the language of the camera.

\section{REFERENCES}

Barry, Peter. Beginning theory: An introduction to literary and cultural theory. UK: Manchester University Press, 2002.

Brewer, Chad. "The Stereotypic Portrayal of Women in Slasher Films: Then Versus Now." Phd diss., B.S., Louisiana State University, 2005.

Cixous, Helen. "The Laugh of the Medusa (Keith Cohen, Paula Cohen, Trans.)". Signs 1.4 (1976): 875-893.

Dovey, Lindiwe., "New Looks: The Rise of African Women Filmmakers". Feminist Africa 16(2011): 18-36.

Goel, Shilpi., "Feminist Literary Criticism". LANGUAGE IN INDIA:Strength for Today and Bright Hope for Tomorrow, 10.4(2010): 403-410.

Gokulsing, Moti., and Wimal Dissanayake. The Indian Popular Cinema. Delhi: Trentham Books Limited, 1998.

Hurlstone, Lise Danielle., Performing Marginal Identities: Understanding the Cultural Significance of Tawa'if and Rudaali Through the Language of the Body in South Asian Cinema. Proquest (1991).

Park, Hyde., "Socialist Feminism: A Strategy for the Women's Movement". Accessed March 26, 2013, http://www.historyisaweapon.com/defcon1/chisocfem.html

Johnston, Clarie. Women's Cinema. Notes on Women's Cinema. London: SEFT, 1991.

Katyal, Anjum. Rudaali: From Fiction to Performance. India: Seagull Books, 2010.

Kristeva, Julia., “Women's Time”. Signs 7.1 (1981): 13-35. 
Mulvey, Laura., "Visual Pleasure and Narrative Cinema." In Film Theory and Criticism: Introductory Readings edited by Leo Braudy \& Marshall Cohen, 833-44. New York: Oxford UP, 1999.

Mulvey, Laura. Visual and Other Pleasures. UK: Palgrave MacMillan, 2009.

Showalter, Elaine., "Women's Time, Women's Space: Writing the History of Feminist Criticism". Tulsa Studies in Women's Literature, 3. 1/2 (1984): 29-43.

Smelik, Anne., "Feminist Film Theory". In The Cinema Book edited by Mieke Bernink and Pam Coo., 491-585. Britain: BFI Publishing, 1991.

Toivonen, Nicole., "Building a Better 'Chick Flick': Representations of Women in Film and Women in the Film Industry". Accessed October 4, 2012, http://www.noizangel.com/school/buildingbetter.pdf 